\title{
Recent Trends in Climate Extreme Indices over Sri Lanka
}

\author{
I. M. Shiromani Priyanthika Jayawardena, D. W. T. Thanuja Darshika, H. M. Roshan C. Herath \\ Department of Meteorology, Colombo, Sri Lanka \\ Email: shirojaya2000@y ahoo.com
}

How to cite this paper: Jayawardena, I.M.S.P., Darshika, D.W.T.T. and Herath, H.M.R.C. (2018) Recent Trends in Climate Extreme Indices over Sri Lanka. American Journal of Climate Change, 7, 586-599. https://doi.org/10.4236/ajcc.2018.74036

Received: June 11, 2018

Accepted: November 16, 2018

Published: November 19, 2018

Copyright ( 92018 by authors and Scientific Research Publishing Inc. This work is licensed under the Creative Commons Attribution International License (CC BY 4.0).

http://creativecommons.org/licenses/by/4.0/

(c) (i) Open Access

\begin{abstract}
Trends in 20 extreme indices of temperature and precipitation are examined for Sri Lanka using high-quality datasets for 19 meteorological stations, for a period between 1980 and 2015. It is evident that annually averaged mean minimum temperatures are increasing across most of Sri Lanka. The difference between maximum and minimum temperatures, diurnal temperature range is decreasing, indicating that the minimum temperature is increasing faster than the maximum temperature. Significant decrease in the annual occurrence of cold nights and increase in the annual occurrence of warm nights are also obvious. When compared with temperature changes, less spatially coherent pattern of change and a lower level of statistical significance were observed in precipitation indices. The annual total precipitation (PRCPTOT) has indicated a significant increasing over $1980-2015$. More than $80 \%$ of stations showed an increasing trend in precipitation indices. The trends in extreme precipitation events such as maximum one-day precipitation, maximum five-day precipitation, and total precipitation on extreme rainfall days (R95p and R99p) are increasing at most locations, indicating that the intensity of the rainfall is increasing. Increase of precipitation extreme trends indicates that occurrence of extreme rainfall events notably influences total annual precipitation in Sri Lanka. Therefore, the observed increases in total rainfall observed in many locations may be due in part to an increase in of extreme rainfall events. Patterns of change in precipitation extremes are more heavily influencing the climate variability by aggravating the variability, significantly influencing climate sensitive sectors such as agriculture and water resource management.
\end{abstract}

\section{Keywords}

Extreme Indices, Climate Change, Trends, Precipitation

\section{Introduction}

Over the last few decades, it has become increasingly evident that the frequency 
and intensity of extreme climate events have been changing especially under the anthropogenically induced climate warming (IPCC, [1]). Climate change can be defined as a trend in one or more climatic variables characterized by a fairly smooth continuous increase or decrease of the average value during the long period of record. Changes in the frequency, intensity, spatial extent, duration, and timing of weather and climate extremes due to climate change can result in increasing vulnerability of people and major economic threat from climate related disasters (IPCC, [1]). Past climate trends based on historical data provide evidence of changing climate conditions. Knowing how the climate has already changed and how those changes have affected the vulnerable sectors such as water resources, Agriculture and food security, Human health and eco system provides insight into what may happen in the future.

A number of studies have been done to investigate the trends in temperature and precipitation records in the world. Using global station data for the period from 1951 and 2003, Alexander et al. [2] found that widespread significant changes in temperature extremes associated with warming with a positive shift in the distribution of daily minimum temperature throughout the globe. Daily maximum temperature indices showed similar changes but with smaller magnitudes. Precipitation changes showed a widespread and significant increase, but the changes are much less spatially coherent compared with temperature change. Vinnikov et al. [3], Groisman and Easterling [4], Karl and Knight [5], Zhang et al. [6], Groisman et al. [7] and Griffiths and Bradley [8] found increases in both precipitation amount and its intensity across the United States and Canada. Trends in Australian temperature and precipitation extremes have been examined broadly. These studies reported widespread increases in warm temperature extremes and decreases in cold temperature extremes, while trends in rainfall extremes show more regionally dependent variations (Hennessy et al. [9]; Plummer et al. [10]; Collins et al. [11]; and Griffiths et al. [12]).

Using temperature data from 210 stations for the period 1971-2000 and precipitation data from 265 stations from 1961 to 2000, Sheikh et al. [13] studied trends in climate extremes indices for the South Asian region. Changes in the frequency of temperature extremes over South Asia are consistent with globally averaged results; warm extremes have become more common and cold extremes less common. Changes in the indices of extreme precipitation are less coherent than those of temperature. However, on average most extreme precipitation indices show increases in the South Asia (Sheikh et al, [13]). Using a high resolution daily gridded rainfall data set, Goswami et al. [14] showed that there are significant rising trends in the frequency and the magnitude of extreme rain events over central India during the monsoon season. This study also showed that significant decreasing trend in the frequency of moderate events (5 to 100 $\mathrm{mm}$ /day rainfall) during the same period, thus leading to no significant trend in the mean rainfall. Using 104 years (1901-2004) of high resolution daily gridded rainfall data over central India, Rajeevan et al. [15] found that the frequency of extreme rainfall events shows significant inter-annual and inter-decadal variations 
in addition to a statistically significant increasing long term trend of $6 \%$ per decade.

Several studies have been conducted relevant to the climate change and climate variability on the basis of trend analysis of climatic variables such as precipitation, temperature in Sri Lanka. Increasing trend in temperature is evident in most parts of the country (Chandrapala [16]; Basnayake [17]; Eriyagama et al. [18]). It has been reported that both mean maximum and mean minimum air temperatures have increased and increase in minimum air temperature contributes more to average increase in annual temperature than day time maximum air temperature (Basnayake [17]).

Previous studies indicated that no clear pattern or trend has been observed in precipitation in Sri Lanka. Some studies identified that average rainfall is showing a decreasing trend (Basnayake [17]) while Premalal [19] observed that heavy rainfall events have become more frequent in central highlands during the recent period. Analyzing fluctuations in rainfall associated with the four climatic seasons using rainfall data for nearly 130 years (1870-2000) from 15 rainfall stations Malmgren et al. [20] identified that decrease of rainfall in higher elevation areas and increase of rainfall in lowlands in the southwestern sector of Sri Lanka during southwest monsoon season. None of the stations show any significant change in Northeast Monsoon precipitation. While analyzing rainfall data for more than 100 years (1895-1996) Jayawardena et al. [21] found that no coherent increase or decrease of rainfall was observed in stations in the wet or dry zones. According to Sheikh et al. [13], declining rainfall has observed (1961-2000) in southern part of Sri Lanka with increasing trends in extreme temperatures. Sheikh et al. [13] identified an increase in the warmest day temperature of the year (TXx), and the coldest night temperature of the year (TNn) over Sri Lanka.

Over the past few years, Sri Lanka has witnessed numerous sequential extreme weather events, such as floods, and droughts causing catastrophic losses to life and property. Most of the previous studies of observed changes in temperature and precipitation extremes in Sri Lanka were used historical data only up to year 2000 (Malmgren et al. [20]; Jayawardena et al. [21] and Sheikh et al. [13]). The purpose of this study is to identify the recent trends in rainfall and temperature indices using recent historical data from 1980 to 2015.

The paper is organized as follows. We briefly describe the definitions of indices discussed in this paper in Section 2. Our results are presented in Section 3 for several different categories of temperature- and precipitation-based indices. A summary of the main findings and concluding remarks are given in Section 4.

\section{Data and Methodology}

Precipitation and temperature indices developed by the World Meteorological Organization-Commission for Climatology (WMO-CCI)/World Climate Research Program (WCRP)/Climate Variability and Predictability (CLIVAR) project's Expert Team on Climate Change Detection and Indices (ETCCDI) (Easterling et al. [22], Alexander et al. [2]) were calculated using daily precipitation, 
daily maximum temperature and daily Minimum temperature data, from 19 surface weather stations (Figure 1 and Table 1) of the Department of Meteorology, Sri Lanka covering the period 1980-2015. The long-term trends for these indices in Sri Lanka during the period 1980-2015 were then examined, using quality-controlled daily station data.

\section{Precipitation Indices and Temperature Indices}

10 extreme precipitation indices, including precipitation totals (PRCPTOT), and 9 extreme temperature indices including diurnal temperature range (DTR), were computed for each of the stations. Data were analyzed by using the RClimDex software, which is developed by ETCCDMI. The package were used and developed in previous studies (Easterling et al. [22], Alexander et al. [2]). The RClimDex was used for quality control of the data by checking for inaccurate data such as negative precipitation, maximum temperature less or equal to minimum temperature, outliers data. After quality control, RClimDex was used to compute climate indices from the daily data. RClimDex calculates 11 precipitation and 9 temperature indices (Table 2 and Table 3), at yearly and (where appropriate) monthly time steps. The details of the indices presented by Table 2 and Table 3.

A 5\% level (large triangles) and 10\% level (small triangles) of statistical significance was also taken into consideration.

\section{Results and Discussion}

Figure 2 presents the time series of mean Maximum and mean Minimum temperature at few stations over wet zone (A and $\mathrm{B})$ and dry and intermediate zone

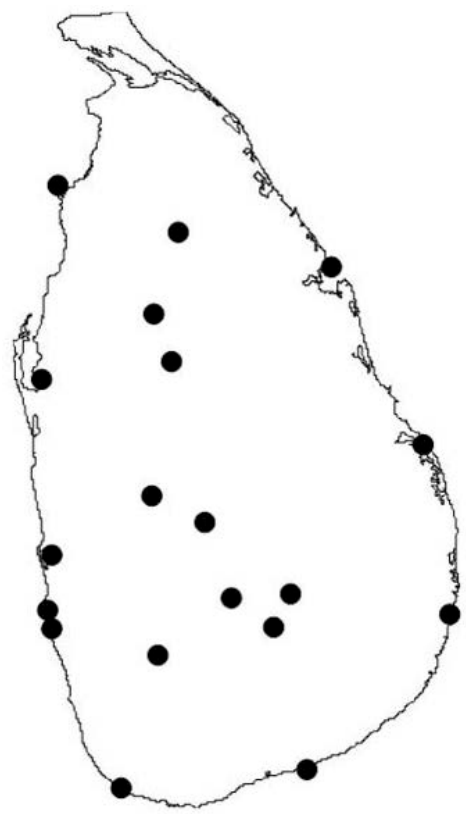

Figure 1. Locations of 19 rainfall stations in Sri Lanka as used in this study. 

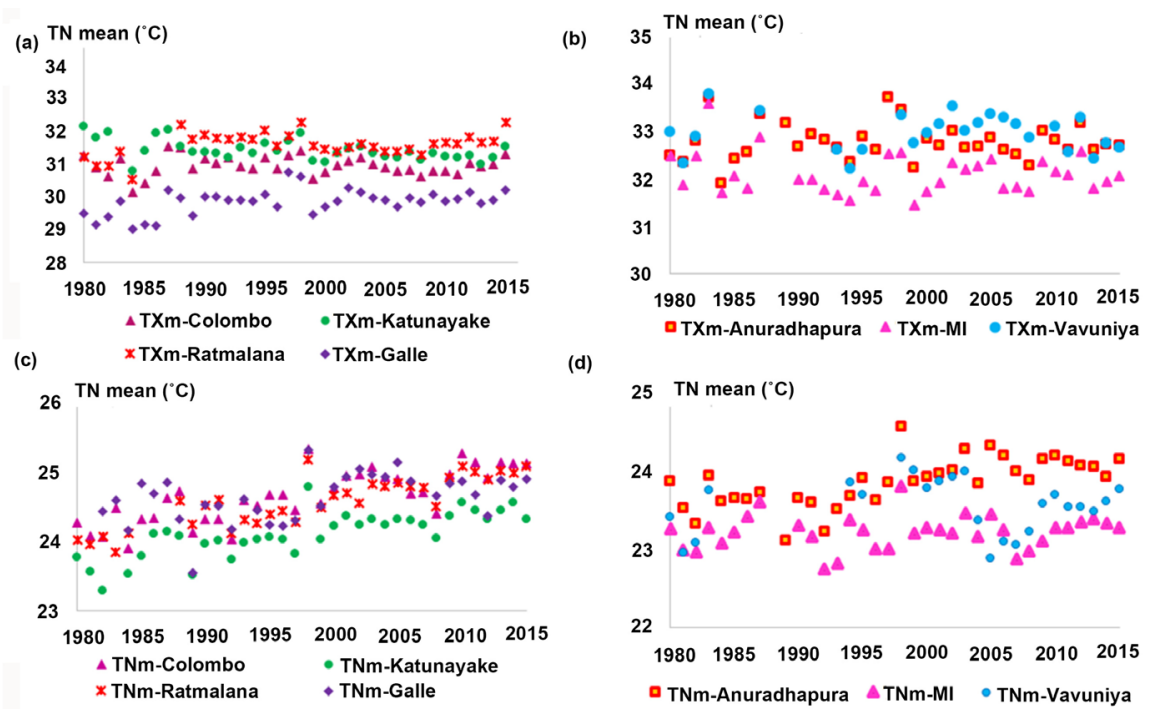

Figure 2. Time series for Maximum mean (a) and Minimum mean temperature (c) at few stations located in wet zone (Colombo, Katunayake, Galle and Ratmalana), Maximum Mean (b) and minimum Mean temperature (d) at few stations located in dry zone ( Anuradhapura, MahaIlluppallama and Vavuniya).

Table 1. Station location details.

\begin{tabular}{|c|c|c|c|}
\hline & Name of the Station & Longitude & Latitude \\
\hline 1 & Ratnapura & 80.4 & 6.68 \\
\hline 2 & Nuwaraeliya & 80.76 & 6.96 \\
\hline 3 & Katugastota & 80.63 & 7.33 \\
\hline 4 & Badulla & 81.05 & 6.98 \\
\hline 5 & Kurunegala & 80.37 & 7.46 \\
\hline 6 & Puttalam & 79.83 & 8.03 \\
\hline 7 & Galle & 80.22 & 6.03 \\
\hline 8 & Ratmalana & 79.88 & 6.81 \\
\hline 9 & Colombo & 79.86 & 6.9 \\
\hline 10 & Hambantota & 81.13 & 6.12 \\
\hline 11 & Katunayake & 79.88 & 7.17 \\
\hline 12 & Anuradhapura & 80.38 & 8.35 \\
\hline 13 & Batticoloa & 81.7 & 7.71 \\
\hline 14 & Trincomalee & 81.25 & 8.58 \\
\hline 15 & Pottuwil & 81.83 & 6.88 \\
\hline 16 & Vavunia & 80.5 & 8.75 \\
\hline 17 & Mannar & 79.91 & 8.98 \\
\hline 18 & Bandarawela & 80.967 & 6.817 \\
\hline 19 & MahaIluppallama & 80.467 & 8.117 \\
\hline
\end{tabular}


Table 2. Precipitation indices.

\begin{tabular}{|c|c|c|c|}
\hline Index & Descriptive Name & Definition & Units \\
\hline PRCPTOT & Wet day precipitation & Annual total precipitation from wet days & $\mathrm{Mm}$ \\
\hline SDII & $\begin{array}{l}\text { Simple daily intensity } \\
\text { index }\end{array}$ & Average precipitation on wet days & $\mathrm{mm} / \mathrm{d}$ \\
\hline $\mathrm{CDD}$ & Consecutive dry days & Maximum number of consecutive dry days & Days \\
\hline CWD & Consecutive wet days & Maximum number of consecutive wet days & Days \\
\hline $\mathrm{R} 10 \mathrm{~mm}$ & Precipitation days & Annual count of days when $R R \geq 10$ & Days \\
\hline $\mathrm{R} 20 \mathrm{~mm}$ & Precipitation days & Annual count of days when $R R \geq 20$ & days \\
\hline $\mathrm{R} 30 \mathrm{~mm}$ & Precipitation days & Annual count of days when $R R \geq 30$ & days \\
\hline R95p & Very wet day precipitation & $\begin{array}{c}\text { Annual total precipitation when } \mathrm{RR}>95^{\text {th }} \\
\text { percentile daily rainfall }\end{array}$ & $\mathrm{mm}$ \\
\hline R99p & Extremely wet day & $\begin{array}{l}\text { Precipitation Annual total precipitation when } \\
\text { RR }>99 \text { th percentile of daily rainfall }\end{array}$ & $\mathrm{mm}$ \\
\hline RX1day & $\begin{array}{l}\text { Maximum 1-day } \\
\text { precipitation }\end{array}$ & Annual maximum 1-day precipitation & $\mathrm{mm}$ \\
\hline RX5day & $\begin{array}{l}\text { Maximum 5-day } \\
\text { precipitation }\end{array}$ & $\begin{array}{l}\text { Annual maximum consecutive } 5 \text {-day } \\
\text { precipitation }\end{array}$ & $\mathrm{mm}$ \\
\hline
\end{tabular}

Table 3. Temperature indices.

\begin{tabular}{|c|c|c|c|}
\hline Index & Descriptive Name & Definition & Units \\
\hline DTR & $\begin{array}{l}\text { Diurnal temperature } \\
\text { range }\end{array}$ & $\begin{array}{l}\text { DTR Diurnal temperature range Monthly mean } \\
\text { difference between TX and TN }\end{array}$ & ${ }^{\circ} \mathrm{C}$ \\
\hline TXx & Hottest day & Monthly highest TX & ${ }^{\circ} \mathrm{C}$ \\
\hline $\mathrm{TNx}$ & Hottest night & Monthly highest TN & ${ }^{\circ} \mathrm{C}$ \\
\hline TXn & Coolest day & Monthly lowest TX & ${ }^{\circ} \mathrm{C}$ \\
\hline $\mathrm{TNn}$ & Coolest night & Monthly lowest TN & ${ }^{\circ} \mathrm{C}$ \\
\hline TN10p & Cool night frequency & Percentage of days when $\mathrm{TN}<10$ th percentile & $\%$ \\
\hline TX10p & Cool day frequency & Percentage of days when $\mathrm{TX}<10$ th percentile & $\%$ \\
\hline TN90p & Hot night frequency & Percentage of days when TN $>$ 90th percentile & $\%$ \\
\hline TX90p & Hot day frequency & Percentage of days when TX $>$ 90th percentile & $\%$ \\
\hline
\end{tabular}

$\mathrm{TX}$ is the daily maximum temperature; $\mathrm{TN}$ is daily minimum temperature.

(C and D) respectively. Even though the rise in mean maximum temperature can be seen in most of the stations, the trend is not significant. Significant increasing trend in minimum temperature is apparent in western coastal area and southern part of Sri Lanka (Figure 2(c)).

Contrary to the mean maximum temperatures, significant increasing trends can be observed in the mean minimum temperatures. Diurnal Temperature Range (DTR), is defined as the difference of daytime maximum temperature and night time minimum temperature. The change in DTR is regional rather than to be global. Many studies have revealed that there is a decrease in DTR since the mid 20th century (Easterling et al. [23]). It is shown clearly that DTR is decreasing 
over most stations except Hambantota and Trincomalee (Figure 3(a)). This decreasing trend is due to the rapidly rising trend of minimum temperatures shown in Figure 1. Two main agricultural seasons in Sri Lanka is Yala season from March to September, and Maha season from October to February (Premalal et al. [24]). Decreasing trend at Anuradhapura located in dry zone is more significant in Maha season (Figure $3\left(b_{1}\right)$ ) than in Yala season (Figure $3\left(b_{2}\right)$ ).

Over $60 \%$ of the stations show significant increasing trends in the percentage of warm nights (Figure $4(a)$ ) and $70 \%$ of the stations show significant decreasing trends in the percentage of cold nights (Figure 4(b)). This means that many stations have seen fewer cold nights and more warm nights during the past 3 - 4 decades. This result is consistent with previous studies conducted by Alexander et al. [2] who found that over $70 \%$ of the land area showed a significant increase in the annual occurrence of warm nights while the occurrence of cold nights showed a similar proportion of significant decrease. Over nearly all parts of the globe both tails of the minimum temperature distribution have warmed at a similar rate (Alexander et al. [2]).

An increasing trend was observed for the annual total rainfall in Sri Lanka as shown in Figure 5, for the period used in this report i.e. 1980-2015. 65\% of stations show significant increasing trend for annual precipitation at $5 \%$ or $10 \%$ level (Figure 5(a)). Simple Daily Intensity of Rainfall (SDII) increasing trend in Anuradhapura, Batticaloa, and Katugastota (Figure 5(b)) at 5\% level and Trincomalee (Figure 5(b)) in 10\% level. It is obvious that Simple Daily Intensity of Rainfall shows a decreasing trend in Puttlum in 10\% level (Figure 5(b)).

Figure 6 and Figure 7 represents the time series of annual total precipitation at few stations over wet zone and simple daily intensity of rainfall at few stations

(a)

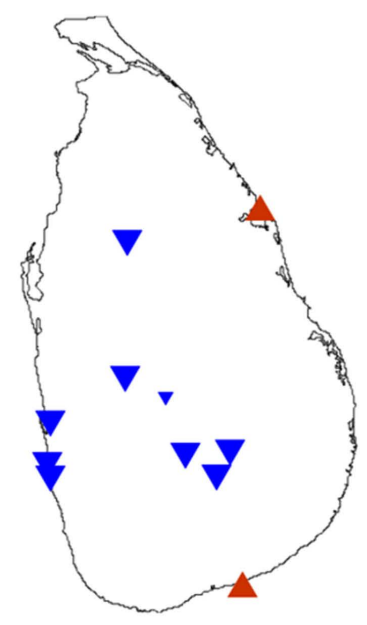

(b) $\quad\left({ }^{\circ} \mathrm{C}\right)$

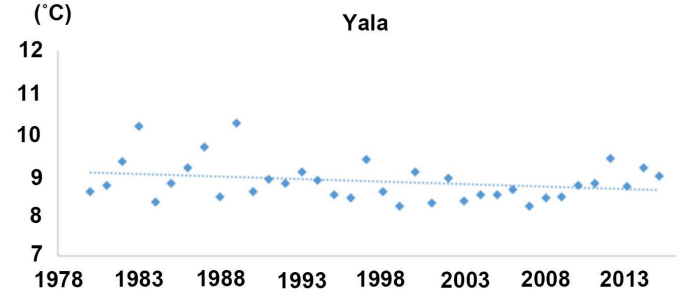

$\left(\mathbf{b}_{2}\right)$

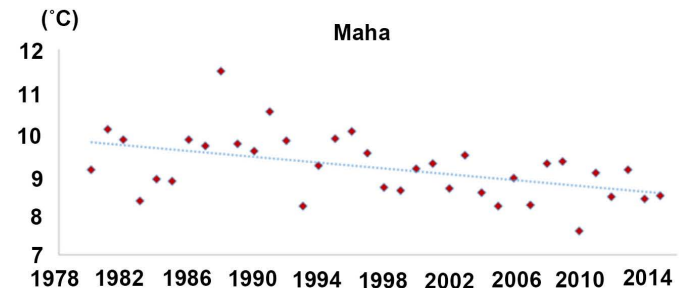

Figure 3. Spatial distribution maps of trends in Diurnal Temperature range (a) and Time series for Diurnal temperature range for Yala $\left(b_{1}\right)$ and Maha $\left(b_{2}\right)$ seasons at Anuradhapura. The upward-pointing red triangles show increasing trends, while the downward-pointing blue triangles indicate decreasing trends. Significant changes at the $5 \%$ level are indicated by large triangles and $10 \%$ level are indicated by small triangles. 


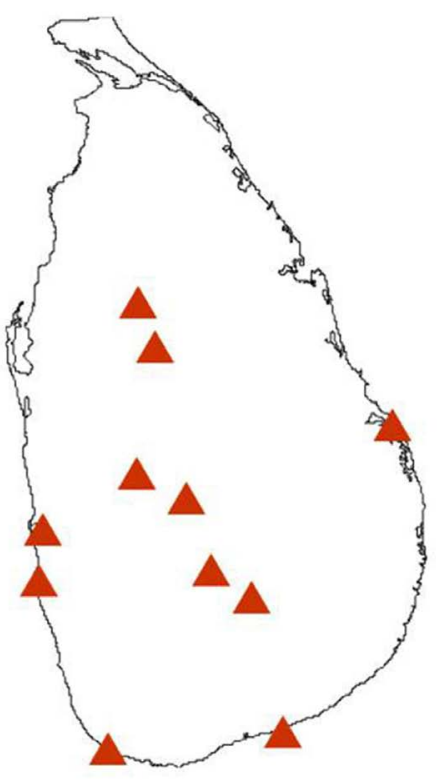

(a)

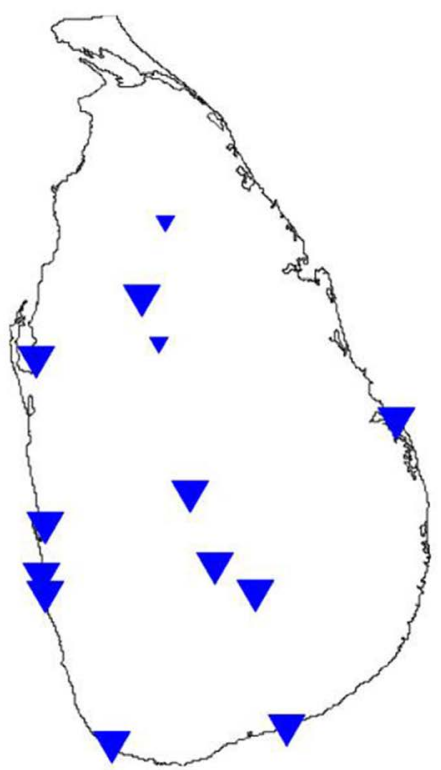

(b)

Figure 4. Spatial distribution maps of trends in Occurrence of warm nights (a) and Occurrence of cold nights (b). The upward-pointing red triangles show increasing trends, while the downward-pointing blue triangles indicate decreasing trends. Significant changes at the $5 \%$ level are indicated by large triangles and $10 \%$ level are indicated by small triangles.

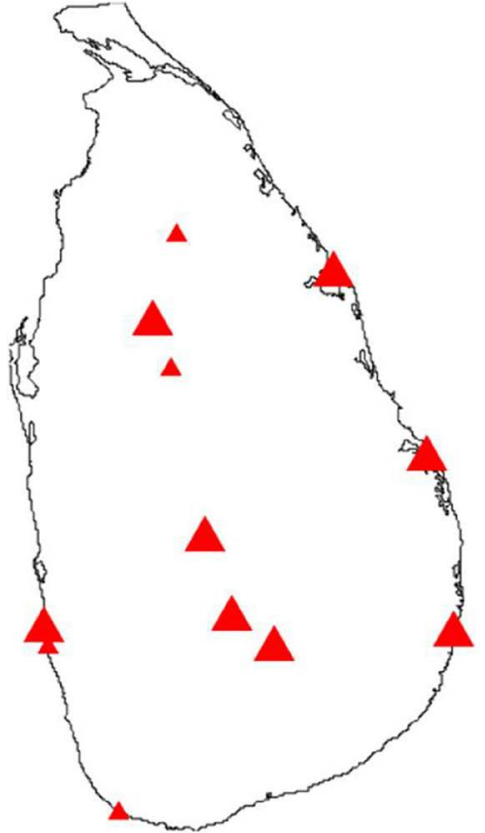

(a)

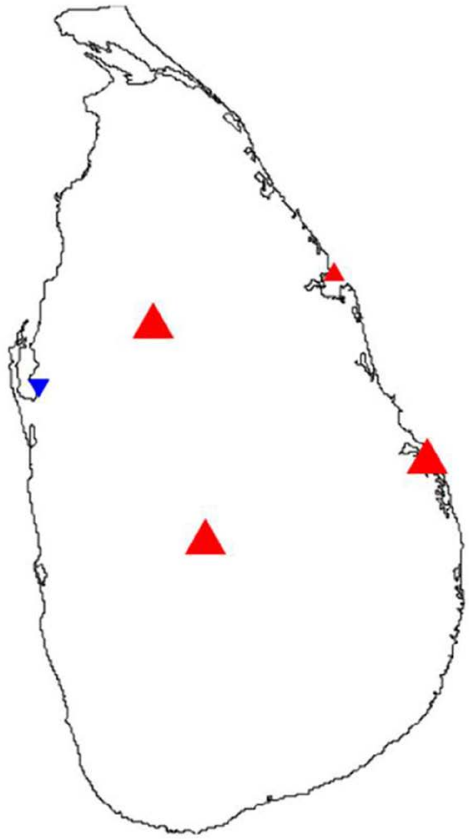

(b)

Figure 5. Spatial distribution maps of trends for annual Total Precipitation (a) and simple daily intensity of rainfall (b). The upward-pointing red triangles show increasing trends, while the downward-pointing blue triangles indicate decreasing trends. Significant changes at the $5 \%$ level are indicated by large triangles and $10 \%$ level are indicated by small triangles. 


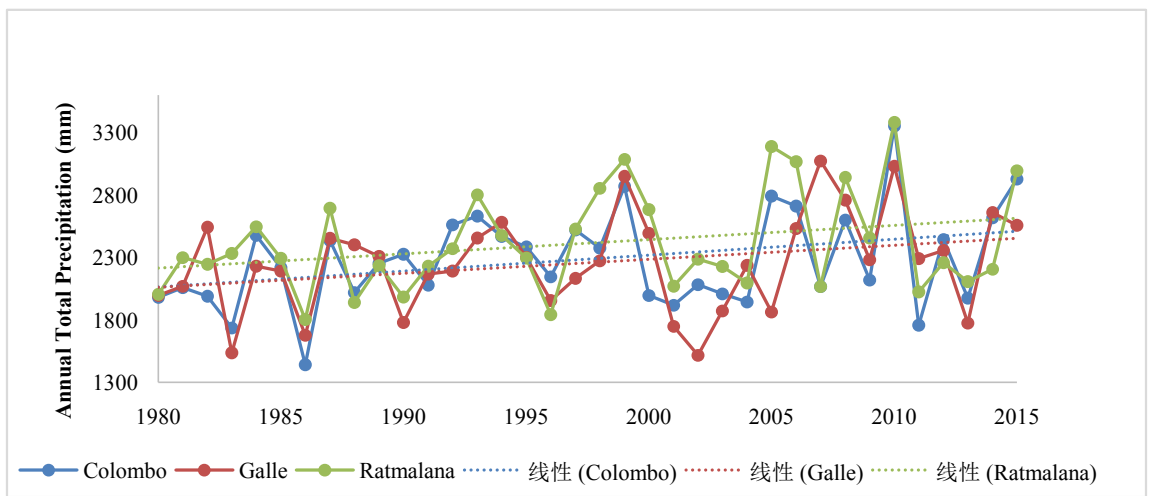

Figure 6. Time series for Annual Total Precipitation at few stations located in wet zone (Colombo, Galle and Ratmalana).

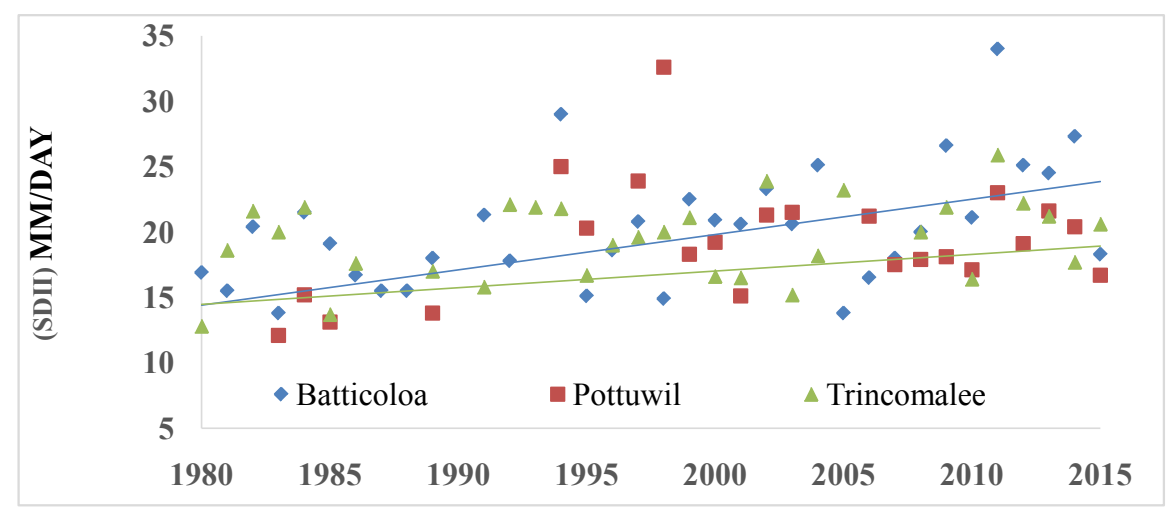

Figure 7. Time series for Simple Daily Intensity of Rainfall (SDII) at few stations located along Eastern Coast (Trincomalee, Batticoloa and Pottuvil).

located in Eastern coast respectively. Within the inter-annual variability, an increasing trend in annual total precipitation is evident in wet zone (Figure 6).

Figure 8 represents the Spatial distribution maps of trends in maximum one-day precipitation (RX1day, Figure 8(a)) and maximum 5-day precipitation (RX5day Figure 8(b)). RX1day trends in increasing except in Puttalum, although relatively few of them are statistically significant. The RX1day showed only positive trends (10\% of stations) with statistical significance, but positive trends were predominant ( $80 \%$ of stations). The RX5day showed also positive trends ( $85 \%$ of stations) with $35 \%$ of statically significance. Comparing with decadal changes, it is found that significant increase in maximal one-day precipitation and maximal five-day precipitation during the period from 2010 to 2015 (Table 4) in station located in all 3 climatic zones. It is evident that $60 \%$ and $50 \%$ increase in maximal one-day and 5 day precipitation amount respectively at Anuradhapura during the from 2010 to 2015. Similarly 110\% and 60\% increase in maximal one-day and 5 day precipitation amount can be seen in Batticoloa for same period compare to 30 year average (Table 4).

90\% stations show non-significant increasing trend in total precipitation on extreme rainfall days (R95p and R99p) but only $20 \%-25 \%$ of the station trends 


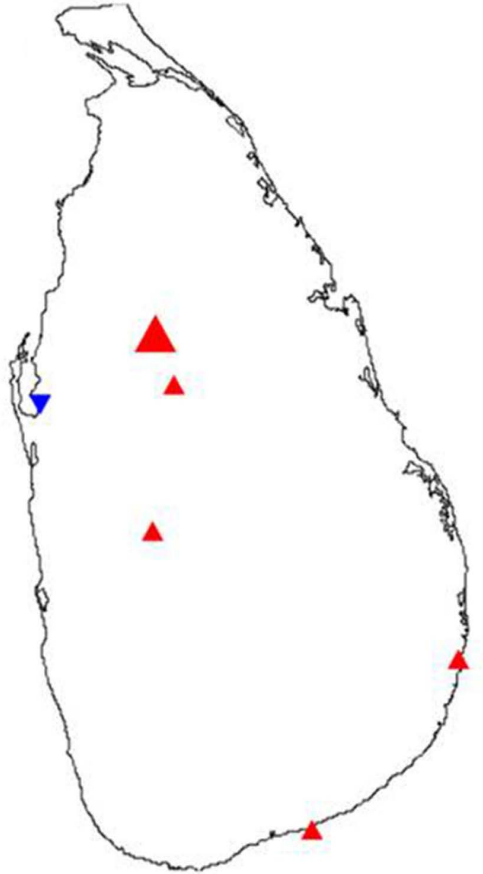

(a)

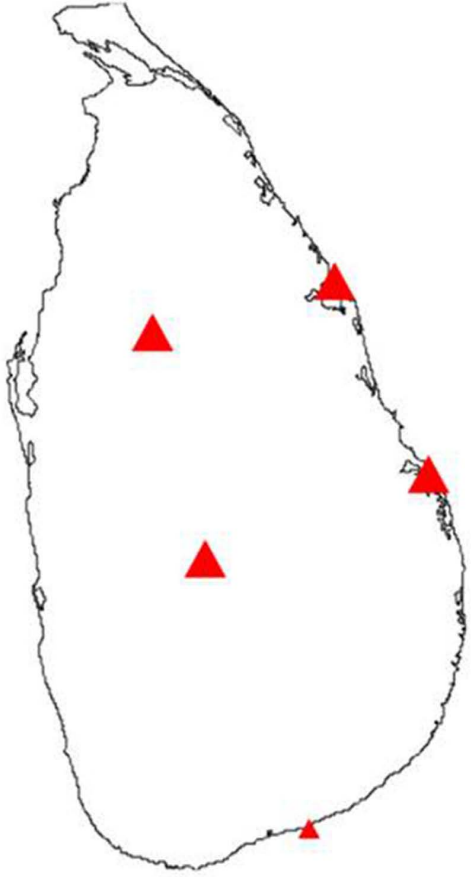

(b)

Figure 8. Spatial distribution maps of trends for maximum one-day precipitation (RX1day) (a) and maximum 5-day precipitation (RX5day) (b). The upward-pointing red triangles show increasing trends, while the downward-pointing blue triangles indicate decreasing trends. Significant changes at the $5 \%$ level are indicated by large triangles and $10 \%$ level are indicated by small triangles.

Table 4. Decadal changes in Extreme Rainfall events defines as Maximum 5 day rainfall amount (mm) and Maximum 1 day rainfall amount $(\mathrm{mm})$.

\begin{tabular}{|c|c|c|c|c|c|c|c|c|c|}
\hline \multirow[b]{3}{*}{ 5Day_Max } & \multicolumn{9}{|c|}{ treme Rainfall Event defined as Maximum Five Day Rainfall (5Day_Max) and Maximum One Day Rainfall (1Day_Max) } \\
\hline & \multicolumn{3}{|c|}{ Dry Zone } & \multicolumn{3}{|c|}{ Intermediate zone } & \multicolumn{3}{|c|}{ Wet zone } \\
\hline & Anuradhapura & Puttatum & Batticoloa & Kurunegala & Badulla & Bandarawela & Katunayake & Katugastota & NuwraEliya \\
\hline average 30 & 175 & 193 & 251 & 221 & 192 & 159 & 142 & 93 & 85 \\
\hline decade 90 & 176 & 189 & 225 & 214 & 168 & 144 & 162 & 94 & 94 \\
\hline decade 2000 & 184 & 180 & 286 & 219 & 171 & 160 & 133 & 90 & 70 \\
\hline 2010-2015 & 281 & 159 & 528 & 301 & 257 & 192 & 146 & 127 & 95 \\
\hline 1Day_Max & Anuradhapura & Puttatum & Batticoloa & Kurunegala & Badulla & Bandarawela & Katunayake & Katugastota & NuwraEliya \\
\hline average 30 & 89 & 113 & 126 & 123 & 95 & 76 & 257 & 177 & 188 \\
\hline decade 80 & 73 & 133 & 130 & 123 & 110 & 78 & 243 & 178 & 217 \\
\hline decade 90 & 99 & 114 & 113 & 115 & 94 & 75 & 265 & 179 & 197 \\
\hline decade 2000 & 94 & 95 & 135 & 131 & 81 & 75 & 252 & 173 & 150 \\
\hline 2010-2015 & 135 & 79 & 200 & 172 & 124 & 91 & 263 & 249 & 198 \\
\hline
\end{tabular}


are significant at the 5\% - 10\% level (Figure 9). Anururadhapura, Katugastota, Batticoloa and Pottuwil stations show significant increasing trend in very wet days and extreme rainfall days (R95p and R99p) (Figure 9) evidencing the increase of precipitation in extreme events at these locations.

Figure 10 represents map of the trends for number of days with precipitation equal to or greater than $10 \mathrm{~mm}$ (a), $20 \mathrm{~mm}$ (b) and $30 \mathrm{~mm}$ (c) rainfall in Sri Lanka. It is shown that $75 \%$ of stations show a significantly increasing trend in number of days with precipitation equal to or greater than $10 \mathrm{~mm}$ and nearly $50 \%$ of stations shows a significantly increasing trend in number of days with precipitation equal to or greater than $20 \mathrm{~mm}$ and $30 \mathrm{~mm}$ rainfall.

Consecutive Wet Days (CWD) and Consecutive Dry Days (CDD) show mixed trends. There is increasing trend in CWD in Katugastota, and decreasing trend in CWD in Nuwaraeliya and Ratnapura. Less consecutive dry days (CDD) is observed in stations located in western coastal areas such as Colombo, Katunayake, Ratmalana and Puttalum.

\section{Summary}

This study presents analyses of the trends in 20 annual extreme indices of temperature and precipitation for Sri Lanka. The analyses were conducted using long term and high-quality datasets for 19 meteorological stations, for a period between 1980 and 2015. The difference between maximum and minimum temperatures is decreasing, indicating that the minimum temperature is increasing

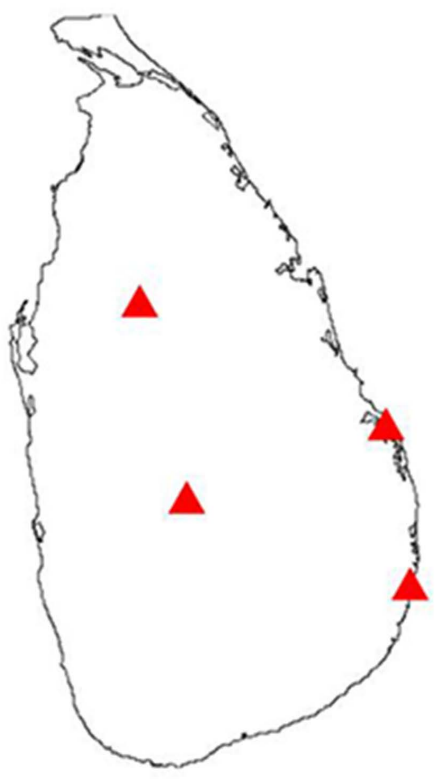

(a)

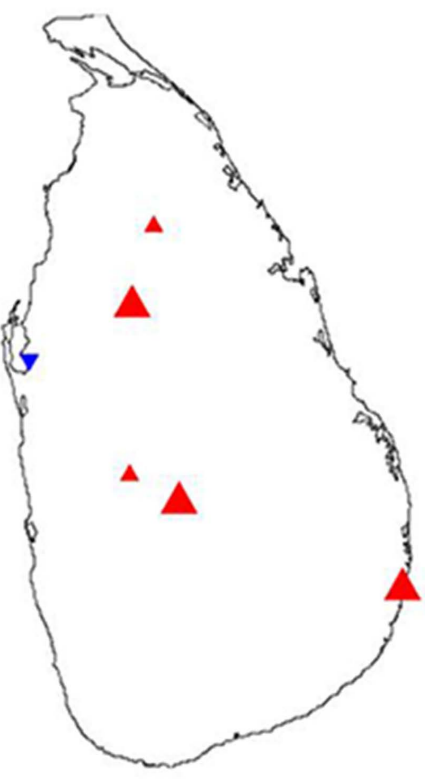

(b)

Figure 9. Spatial distribution maps of trends for very wet days (a) and Extremely wet days (b), The upward-pointing red triangles show increasing trends, while the downward-pointing blue triangles indicate decreasing trends. Significant changes at the $5 \%$ level are indicated by large triangles and $10 \%$ level are indicated by small triangles. 


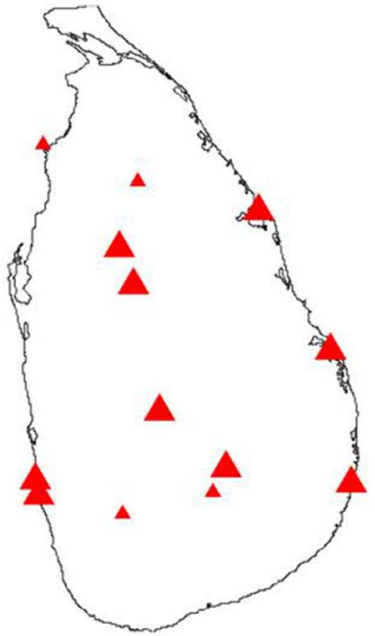

(a)

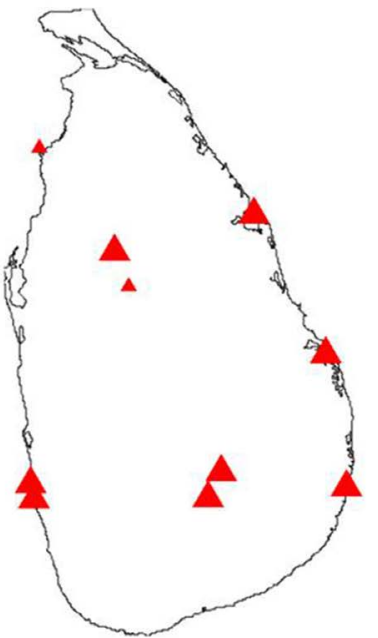

(b)

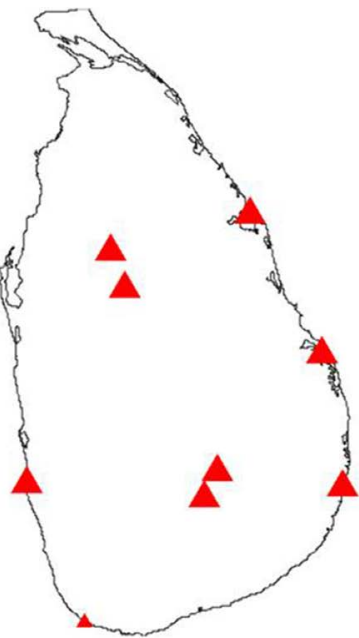

(c)

Figure 10. Spatial distribution maps of trends for number of days, above $10 \mathrm{~mm}$ rainfall (a), above $20 \mathrm{~mm}$ rainfall (b) and above $30 \mathrm{~mm}$ rainfall (c). The upward pointing red triangles show increasing trends, while the downward-pointing blue triangles indicate decreasing trends. Significant changes at the $5 \%$ level are indicated by large triangles and $10 \%$ level are indicated by small triangles.

faster than the maximum temperature. It is evident that annually averaged mean minimum temperatures are increasing across most of Sri Lanka. Significant decrease in the annual occurrence of cold nights and increase in the annual occurrence of warm nights are also obvious.

When compared with temperature changes, less spatially coherent pattern of change and a lower level of statistical significance were observed in precipitation indices. Some of the indices in this study can be good indicators for climate extremes in Sri Lanka. The annual total precipitation (PRCPTOT) has indicated a significant increasing over $1980-2015$. More than $80 \%$ of stations showed an increasing trend in precipitation indices. Nearly $75 \%$ and $65 \%$ of the station showed significant increasing trend in annual total precipitation and number of days above $10 \mathrm{~mm}$ rainfall at the $5 \%-10 \%$ level. The trends in extreme precipitation events such as maximal one-day precipitation, maximal five-day precipitation, and total precipitation on extreme rainfall days (R95p and R99p) are increasing at most locations, indicating that the intensity of the rainfall is increasing. Increase of precipitation extreme trends indicate that occurrence of extreme rainfall events notably influence total annual precipitation in Sri Lanka. Therefore, the observed increases in total rainfall observed in many locations may be due in part to an increase in of extreme rainfall events. Patterns of change in precipitation extremes are more heavily influencing the climate variability by aggravating the variability, significantly influencing climate sensitive sectors such as agriculture and water resource management.

\section{Conflicts of Interest}

The authors declare no conflicts of interest regarding the publication of this paper. 


\section{References}

[1] IPCC (2012) Managing the Risks of Extreme Events and Disasters to Advance Climate Change Adaptation. A Special Report of Working Groups I and II of the Intergovernmental Panel on Climate Change. [Field, C.B., Barros, V., Stocker, T.F., Qin, D., Dokken, D.J., Ebi, K.L., Mastrandrea, M.D., Mach, K.J., Plattner, G.-K., Allen, S.K., Tignor, M. and Midgley, P.M. (Eds.)]. Cambridge University Press, Cambridge, UK and New York, $582 \mathrm{p}$.

[2] Alexander, L.V., Zhang, X., Peterson, T.C., Caesar, J., Gleason, B., Klein Tank, A.M.G., Haylock, M., Collins, D., Trewin, B., Rahimzadeh, F. and Tagipour, A. (2006) Global Observed Changes in Daily Climate Extremes of Temperature and Precipitation. Journal of Geophysical Research: Atmospheres, 111, Issue D5. https://doi.org/10.1029/2005JD006290

[3] Vinnikov, K.Y., Groisman, P.Y. and Lugina, K.M. (1990) Empirical Data on Contemporary Global Climate Changes (Temperature and Precipitation). Journal of Climate, 3, 662-677. https://doi.org/10.1175/1520-0442(1990)003<0662:EDOCGC>2.0.CO;2

[4] Groisman, P.Y. and Easterling, D.R. (1994) Variability and Trends in Total Precipitation and Snowfall over the United States and Canada. Journal of Climate, 7, 184-205. https://doi.org/10.1175/1520-0442(1994)007<0184:VATOTP >2.0.CO;2

[5] Karl, T.R. and Knight, R.W. (1998) Secular Trends of Precipitation Amount, Frequency, and Intensity in the United States. Bulletin of the American Meteorological Society, 79, 231-241. https://doi.org/10.1175/1520-0477(1998)079<0231:STOPAF>2.0.CO;2

[6] Zhang, X., Vincent, L.A., Hogg, W.D. and Niitsoo, A. (2000) Temperature and Precipitation Trends in Canada during the 20th Century. Atmosphere-Ocean, 38, 395-429. https://doi.org/10.1080/07055900.2000.9649654

[7] Groisman, P.Y., Knight, R.W., Easterling, D.R., Karl, T.R., Hegerl, G.C. and Razuvaev, V.N. (2005) Trends in Intense Precipitation in the Climate Record. Journal of climate, 18, 1326-1350. https://doi.org/10.1175/JCLI3339.1

[8] Griffiths, M.L. and Bradley, R.S. (2007) Variations of Twentieth-Century Temperature and Precipitation Extreme Indicators in the Northeast United States. Journal of Climate, 20, 5401-5417. https://doi.org/10.1175/2007JCLI1594.1

[9] Hennessy, K.J., Suppiah, R. and Page, C.M. (1999) Australian Rainfall Changes, 1910-1995. Australian Meteorological Magazine, 48, 1-13.

[10] Plummer, N., Salinger, M.J., Nicholls, N., Suppiah, R., Hennessy, K.J., Leighton, R.M., Trewin, B., Page, C.M. and Lough, J.M. (1999) Changes in Climate Extremes over the Australian Region and New Zealand during the Twentieth Century. Climatic Change, 42, 183-202. https://doi.org/10.1023/A:1005472418209

[11] Collins, D.A., Della-Marta, P.M., Plummer, N. and Trewin, B.C. (2000) Trends in Annual Frequencies of Extreme Temperature Events in Australia. Australian $\mathrm{Me}$ teorological Magazine, 49, 277-292.

[12] Griffiths, G.M., Chambers, L.E., Haylock, M.R., Manton, M.J., Nicholls, N., Baek, H.-J., Choi, Y., Della-Marta, P.M., Gosai, A., Iga, N., Lata, R., Laurent, V., Maitrepierre, L., Nakamigawa, H., Ouprasitwong, N., Solofa, D., Tahani, L., Thuy, D.T., Tibig, L., Trewin, B., Vediapan, K. and Zhai, P. (2005) Change in Mean Temperature as a Predictor of Extreme Temperature Change in the Asia-Pacific Region. International Journal of Climatology, 25, 1301-1330 https://doi.org/10.1002/joc.1194

[13] Sheikh, M.M., Manzoor, N., Ashraf, J., Adnan, M., Collins, D., Hameed, S., Manton, M.J., Ahmed, A.U., Baidya, S.K., Borgaonkar, H.P. and Islam, N. (2015) Trends in 
Extreme Daily Rainfall and Temperature Indices over South Asia. International Journal of Climatology, 35, 1625-1637. https://doi.org/10.1002/joc.4081

[14] Goswami, B.N., Venugopal, V., Sengupta, D., Madhusoodanan, M.S. and Xavier, P.K. (2006) Increasing Trend of Extreme Rain Events over India in a Warming Environment. Science, 314, 1442-1445. https://doi.org/10.1126/science.1132027

[15] Rajeevan, M., Bhate, J. and Jaswal, A.K. (2008) Analysis of Variability and Trends of Extreme Rainfall Events over India Using 104 Years of Gridded Daily Rainfall Data. Geophysical Research Letters, 35, L18707. https://doi.org/10.1029/2008GL035143

[16] Chandrapala, L. (1996) Long Term Trends of Rainfall and Temperature in Sri Lanka. In: Abrol, Y.P., Gadgil, S. and Pant, G.B., Eds., Climate Variability and Agriculture, Narosa Publishing House, New Delhi, 150-152.

[17] Basnayake, B.R.S.B., Fernando, T.K. and Vithanage, J.C. (2002) Variation of Air Temperature and Rainfall during Yala and Maha Agricultural Seasons. Proceedings of the 58 th Annual Session of Sri Lanka Association for the Advancement of Science (SLASS), Section E1, p. 212.

[18] Eriyagama, N., Smakhtin, V., Chandrapala, L. and Fernando, K. (2010) Impacts of Climate Change on Water Resources and Agriculture in Sri Lanka: A Review and Preliminary Vulnerability Mapping. International Water Management Institute, Colombo, 51 p. (IWMI Research Report 135). https://doi.org/10.5337/2010.211

[19] Premalal, K.H.M.S. (2009) Weather and Climate Trends, Climate Controls \& Risks in Sri Lanka. Presentation made at the Sri Lanka Monsoon Forum, April 2009. Department of Meteorology, Sri Lanka.

[20] Malmgren, B.A., Hulugalla, R., Hayashi, Y. and Mikami, T. (2003) Precipitation Trends in Sri Lanka since the 1870s and Relationships to El Niño-Southern Oscillation. International Journal of Climatology, 23, 1235-1252. https://doi.org/10.1002/joc.921

[21] Jayawardene, H.K.W.I., Sonnadara, D.U.J. and Jayewardene, D.R. (2005) Trends of Rainfall in Sri Lanka over the Last Century. Sri Lankan Journal of Physics, 6, 7-17.

[22] Easterling, D.R., Alexander, L.V., Mokssit, A. and Detemmerman, V. (2003) CCI/CLIVAR Workshop to Develop Priority Climate Indices. Bulletin of the American Meteorological Society, 84, 1403-1407.

[23] Easterling, D.R., Horton, B., Jones, P.D., Peterson, T.C., Karl, T.R., Parker, D.E., Salinger, M.J., Razuvayev, V., Plummer, N., Jamason, P. and Folland, C.K. (1997) Maximum and Minimum Temperature Trends for the Globe. Science, 277, 364-367. https://doi.org/10.1126/science.277.5324.364

[24] Premalal, K.H.M.S., Niranjan, F., Uddika, N.P.C., Bantilan, C.S. and Singh, N.P. (2013) Vulnerability to Climate Change: Adaptation Strategies and Layers of Resilience: Climatic trends in Sri Lanka Agro-climatic Analysis, Research Report No. 15. Working Paper. ICRISAT, Patancheru, Telangana, India. 